\title{
Penguatan Kapasitas Puskesmas Sebagai Organisasi Publik (Kajian dalam Perspektif Teori Organisasi)
}

\author{
Yusuf Gabriel Maniagasi \\ Program Studi Ilmu Pemerintahan Jurusan Ilmu Politik Fakultas Ilmu Sosial dan Ilmu Politik \\ Universitas Cenderawasih Jayapura, Papua, Indonesia, 99351 \\ Email :gabrielpapua34@gmail.com
}

\begin{abstract}
Many of our society at villages in Papua Province are not getting maximum health services by puskesmas for various reasons. Unfortunatly, the condition of the puskemas-which can be interpreted as the face and image of the government-does not indicated the expected the attraction to visit. People prefer to visit local public hospital or to practice doctors in the afternoon. This situation affirms the poor image of puskesmas. What is wrong in Puskesmas?. This question should be disclosed to fined what is really with our healh centers? The aims of this study was to find the root of the problems of lack of capacity of puskesmas as public organization in doing health service to society. This study uses literature study methods supported by data and documentation. The results of the study shows that to solve the problems related to puskesmas as the basis of public healt service hence there are two aspects that must be done that are 1). Structuring Organizational Structure and 2). Changing Organizational Culture. As the conlucion of this study is to bring well and qualified health service to the community can be started by optimizing task and function of puskesmas as public organization followed by commitment, good leadership, change of perspective, regulation arrangement and strong will to improve the performance of puskesmas.
\end{abstract}

Keyword: Puskesma; Public Organizational; Public Service

\begin{abstract}
Abstrak
Banyak masyarakat kita, di pedesaan (baca : kampung-kampung) di Provinsi Papua kurang mendapatkan pelayanan maksimal oleh Pusat Kesehatan Masyarakat (Puskesmas) karena beragam alasan. Sayangnya, keadaan Puskesmas - yang dapat dimaknai sebagai wajah dan citra pemerintahtidak menunjukkan keadaan yang diharapkan, bahkan nyaris kehilangan daya tarik untuk dikunjungi. Masyarakat lebih memilih berkunjung ke rumah sakit umum daerah (RSUD) atau ke dokter praktek pada sore hari. Keadaan ini memberi penegasan pada buruknya citra Puskesmas. Ada apa di Puskesmas? Pertanyaan ini patut diungkapkan untuk ditemukan ada apa sebenarnya dengan Puskesmas-Puskesmas kita. Tujuan penelitian untuk menemukan akar masalah lemahnya kapasitas puskesmas sebagai organisasi publik dalam melakukan pelayanan kesehatan kepada masyarakat. Kajian ini menggunakan metode studi literatur yang didukung dengan data-data dan dokument. Hasil kajian menunjukkan untuk menyelesaikan masalah-masalah yang berkaitan dengan Puskesmas sebagai basis pelayanan kesehatan masyarakat maka ada dua aspek yang harus dilakukan yakni 1). Penataan Struktur Organisasi Puskesmas dan 2). Melakukan Perubahan Budaya Organisasi. Sebagai simpulan kajian ini adalah untuk mendekatkan pelayanan kesehatan yang layak dan bermutu prima kepada masyarakat dapat dimulai dengan optimalisasi tugas dan fungsi Puskesmas sebagai organisasi publik yang diikuti dengan komitmen, kepemimpinan, perubahan cara pandang, pengaturan regulasi, dan kemauan yang kuat untuk memperbaiki kinerja puskesmas
\end{abstract}

Kata Kunci : Puskesmas; Organisasi Publik; Pelayanan Publik

Link DOI : http://dx.doi.org/10.31314/pjia.7.1.70-79.2018 


\section{PENDAHULUAN}

Salah satu tugas pemerintah adalah melakukan pelayanan kepada masyarakat dalam berbagai bidang, seperti pendidikan, kesehatan, transportasi, hukum, pertanian, peternakan, pekerjaan umum, dan lain-lain. Pelayanan dalam bidang-bidang tersebut merupakan urusan wajib yang mau tidak mau atau suka tidak suka harus dilakukan pemerintah bagi masyarakat.

Pelayanan kesehatan sebagai urusan wajib merupakan hal utama yang pemenuhannya tidak bisa ditunda, karena terkait dengan keselamatan nyawa manusia. Oleh sebab itu, dibutuhkan upaya dan kerja keras pemerintah untuk melakukan pelayanan yang baik dan benar sesuai standar pelayanan kesehatan yang normal dan manusiawi.

Jika menyinggung soal urusan kesehatan masyarakat maka ada banyak aspek yang harus menjadi perhatian, misalnya kebersihan lingkungan, perilaku hidup sehat, pola konsumsi, pengetahuan, wawasan, persepsi, harapan hidup, ketersediaan pangan, penyediaan air bersih, tenaga medis, peralatan kesehatan, manajemen pelayanan kesehatan, ketersediaan obat-obatan, anggaran bahkan kebijakan dan regulasi. Cukup kompleks memang jika berhadapan dengan urusan mengenai kesehatan dan keselamatan manusia. Walaupun keadaannya demikian, Pemerintah tidak punya alasan untuk menolak atau tidak melakukannya. Hal ini menjadi urusan wajib yang haram hukumnya jika tidak dilaksanakan. Oleh sebab itu, dibutuhkan konsentrasi dan kemampuan aparat birokrasi untuk melakukan urusan ini.

Fakta menyebutkan bahwa tidak sedikit masyarakat kita, khususnya yang berada di daerah pedesaan (baca : kampung-kampung) di Papua kurang mendapatkan pelayanan maksimal oleh Pusat Kesehatan Masyarakat (Puskesmas) Copyright (O 2018, Publik: (Jurnal Ilmu Administasi), ISSN : 2301-573X (Print), ISSN: 2581-2084 (Online) karena beragam alasan. Tidak sedikit alasan bisa dikemukakan untuk menjustifikasi lambannya pelayanan Puskesmas terhadap masyarakat. Padahal, Puskesmas merupakan bukti kehadiran pemerintah dalam melayani masyarakat di bidang ini. Sayangnya, keadaan Puskesmas - yang dapat dimaknai sebagai wajah dan citra pemerintah-tidak menunjukkan keadaan yang diharapkan, bahkan nyaris kehilangan daya tarik untuk dikunjungi. Sebaliknya masyarakat lebih memilih berkunjung ke rumah sakit umum daerah (RSUD) atau ke dokter praktek pada sore hari. Keadaan ini memberi penegasan pada buruknya citra Puskesmas. Ada apa di Puskesmas? Pertanyaan ini patut diungkapkan untuk ditemukan ada apa sebenarnya dengan PuskesmasPuskesmas kita?

Dalam perspektif Ilmu Administrasi Publik, Puskesmas dipandang sebagai Organisasi Publik. Artinya bahwa Puskesmas dilihat sebagai sebuah organisasi. Pada konteks ini Puskesmas dikaji dalam konsep Teori Organisasi. Teori Organisasi memandang bahwa manusia merupakan mahluk sosial yang cenderung bermasyarakat serta mengatur dan mengorganisasikan kegiatannya untuk mencapai tujuan. Hanya saja, manusia memiliki keterbatasan-keterbatasan tertentu yang menjadi sebab ketidakmampuannya mewujudkan apa yang akan dicapainya. Atas dasar inilah kemudian ia membutuhkan orang lain dan menjalin kerjasama.

Ada banyak pandangan para ahli tentang organisasi, misalnya Ernest Dale menyebutkan Organisasi sebagai suatu proses perencanaan yang meliputi penyusunan, pengembangan, dan pemeliharaan suatu struktur atau pola hubungan kerja dari orang-orang dalam suatu kerja kelompok. Sementara Cyril Soffer, mengatakan Organisasi adalah i), ISSN: 2301-573X (Print), ISSN: 2581-2084 
perserikatan orang-orang yang masingmasing diberi peran tertentu dalam suatu sistem kerja dan pembagian tugas-tugas. Meski beragam batasan atau definisi para ahli mengenai Organisasi namun secara umum dapat dikatakan bahwa Organisasi adalah Kelompok orang yang secara bersama-sama ingin mencapai tujuan. Berikut adalah ciri-ciri organisasi yakni : a). Sebuah institusi sosial yang terdiri atas kumpulan orang dengan berbagai pola interaksi yang ditetapkan. b). Lembaga tersebut dikembangkan untuk mencapai tujuan. c). Dikoordinasikan dan disusun secara sadar dan terencana. d). Instrumen sosial yang mempunyai batasan yang relatif dapat diidentifikasi.

Secara Ilmu Pengetahuan, Teori Organisasi dapat dibedakan menjadi Teori Organisasi Klasik, Teori Organisasi Neoklasik, dan Teori Organisasi Modern. Teori Klasik membagi Organisasi menjadi tiga bagian yakni Birokrasi, Administrasi dan manajemen ilmiah.

Teori Organisasi Klasik lebih dikenal dengan istilah "teori tradisional" yang mulai berkembang pada tahun 1800an atau sekitar abad 19. Dalam teori ini organisasi digambarkan sebagai sebuah lembaga yang tersentralisasi dan tugastugasnya terspesialisasi serta memberikan petunjuk mekanistik struktural yang kaku dan tidak memberi ruang bagi kreatifitas. Disini organisasi digambarkan seperti tuts piano dimana masing-masing nada mempunyai spesialisasi (do.. re.. mi.. fa.. so.. la.. si..) dimana apabila tiap nada dirangkai maka akan tercipta lagu yang indah, begitu juga dengan organisasi. Dalam perspektif ini organisasi juga dipandang sebagai struktur hubungan, kekuasaan-kekuasaan, tujuan-tujuan, peranan-peranan, kegiatan-kegiatan, komunikasi dan faktor-faktor lain yang akan sempurna jika bekerja sama. Teori
Organisasi klasik sepenuhnya menguraikan anatomi organisasi formal. Empat unsur pokok yang selalu muncul dalam organisasi formal: Satu, Sistem kegiatan yang terkoordinasi. Dua, Ada kelompok orang. Tiga, Kerjasama. Empat, Kekuasaan \& Kepemimpinan. Sedangkan menurut penganut teori klasik suatu organisasi tergantung pada empat kondisi pokok: Kekuasaan, Saling melayani, Doktrin, dan Disiplin. Berikut adalah pilarpilar dasar dalam Organisasi Formal adalah: satu, Pembagian kerja (untuk koordinasi). Dua, Proses Skalar \& Fungsional (proses pertumbuhan vertikal dan horizontal). Tiga, Struktur (hubungan antar kegiatan). Empat, Rentang kendali (satu atasan mampu mengendalikan berapa banyak bawahan.

Teori Klasik berkembang dalam 3 Aliran, yakni : Birokrasi, Administrasi, dan Manajemen Ilmiah. Semua teori diatas dikembangkan sekitar tahun 1900-1950. Pelopor teori ini kebanyakan dari negara yang berbentuk kerajaan, seperti "Mesir, Cina \& Romawi".

Teori Birokrasi Dikemukakan oleh "Max Weber" dalam bukunya "The Protestant Ethic and Spirit of Capitalism" dan "The Theory of Social and Economic Organization". Istilah Birokrasi berasal dari kata Legal-Rasional: "Legal" disebabkan adanya wewenang dari seperangkat aturan prosedur dan peranan yang dirumuskan secara jelas. Sedangkan "Rasional" karena adanya penetapan tujuan yang ingin dicapai.

Berikut adalah karekteristik birokrasi (ideal) menurut Max Weber: Mengenal adanya Pembagian kerja; ada Hirarki wewenang; Programnya harus rasional; Sistem Prosedur; Sistem Aturan hak-kewajiban; Hubungan antar pribadi yang bersifat impersonal. 
Teori ini dikembangkan oleh Henry Fayol, Lyndall Urwick dari Eropa dan James D. Mooney, Allen Reily dari Amerika.

Henry Fayol (1841-1925): Seorang industrialis asal Perancis tahun 1916 menulis sebuah buku "Admistration industrtrielle et Generale" diterjemahkan dalam Bahasa Inggris 1926 dan baru dipublikasikan di Amerika 1940, menyebutkan ada 14 KAIDAH MANAJEMEN yang menjadi dasar Teori Administrasi, sebagai berikut : Pembagian kerja; Wewenang \& tanggung jawab; Disiplin; Kesatuan Perintah; Kesatuan pengarahan; Mendahulukan kepentingan umum; Balas jasa; Sentralisasi; Rantai Skalar; Aturan; Keadilan; Kelanggengan personalia; Inisiatif; Semangat korps.

Fayol membagi kegiatan industri menjadi 6 kelompok : satu, Kegiatan Teknikal (Produksi, Manufaktur, Adaptasi). Dua, Kegiatan Komersil (Pembelian, Penjualan, Pertukaran). Tiga, Kegiatan Financial (penggunaan optimum modal). Empat, Kegiatan Keamanan. Lima, Kegiatan Akuntansi. Enam, Kegiatan Manajerial atau "Fayol's Functionalism" yaitu: Perencanaan; Pengorganisasian; Pemberian Perintah; Pengkoordinasian; Pengawasan.

\section{James D. Mooney \& Allen Reilly} (1931) menerbitkan buku "Onward Industry" yang pada intinya menyebutkan bahwa "Koordinasi Merupakan Faktor terpenting dalam perencanaan organisasi". Tiga prinsip yang harus diterapkan dalam sebuah organisasi menurut mereka adalah: Prinsip Koordinasi; Prinsip Skalar \& Hirarkis; dan Prinsip Fungsional.

Teori Manajemen Ilmiah. Teori ini dikembangkan pada tahun 1900 oleh Frederick Winslow Taylor. Ia mendefinisikan Manajemen Ilmiah sebagai "Penerapan metode ilmiah pada studi, analisa dan pemecahan masalah adanya perbedaan karekteristik individ
Copyright $\odot$ 2018, Publik : (Jurnal Ilmu Administrasi), ISSN: 2301-573X (Print), ISSN: 2581-2084 (Online) organisasi" atau "Seperangkat mekanisme untuk meningkatkan efesiensi kerja". Frederick Winslow Taylor menuangkan ide dalam tiga makalah: Shop Management; The Principle of Scientific Management, dan Testimony before the Special House Comitte. Dari tiga makalah tersebut lahir sebuah buku "Scientific Management". Berkat jasa-jasanya, sampai sekarang konsepnya masih dipergunakan pada praktek manajemen modern maka Frederick Winslow Taylor dijuluki sebagai Bapak Manajemen Ilmiah

Empat kaidah Manajemen menurut Frederick W. Taylor:

a. Menggantikan metode kerja dalam praktek dengan metode atas dasar ilmu pengetahuan.

b. Mengadakan seleksi, latihan dan pengembangan karyawan

c. Pengembangan ilmu tentang kerja, seleksi, latihan dan pengembangan secara ilmiah perlu integrasikan.

d. Perlu dikembangkan semangat dan mental karyawan untuk mencapai manfaat Manajemen Ilmiah

Teori Organisasi Neoklasik. Teori ini muncul dan dikenal dengan "Teori Hubungan Manusiawi”. Kemunculan teori ini sebagai akibat ketidakpuasan dengan teori organisasi klasik. Ia hadir dan memberi penyempurnaan pada teori organisasi klasik. Teori ini menekankan pada pentingnya "aspek psikologis" dan "sosial karyawan" (sebagai individu ataupun kelompok kerja). Pelopor teori ini antara lain Hugo Munsterberg (1913). Munsterberg muncul dengan topik "Psycology and Insdustrial Effeciancy". Buku yang ditulis ini kemudian menjadi semacam jembatan penghubung antara manajemen ilmiah dan neoklasik. Hugo Munsterberg kemudian dikenal sebagai pencetus Psikologi Industri. Inti pandangan Hugo Munsterberg adalah penekanan pada adanya perbedaan karekteristik individu 
dalam organisasi dan mengingatkan pada adanya pengaruh sosial dan budaya terhadap organisasi. Sejenak menengok kebelakang bahwa munculnya Teori Organisasi Neoklasik ini diawali dengan inspirasi percobaan yang dilakukan di Pabrik Howthorne tahun 1924 milik perusahaan Western Elektric di Cicero yang disponsori oleh Lembaga Riset Nasional Amerika. Percobaan yang dilakukan Elton Mayo periset dari Western Electric yang menyimpulkan bahwa pentingnya memperhatikan Insentif-Upah dan Kondisi Kerja karyawan yang dianggap sebagai faktor penting bagi peningkatan produktifitas. Dalam pembagian kerja Teori Organisasi Neoklasik memandang diperlukan adanya: Partisipasi; Perluasan kerja; dan Manajemen bottom-up.

Teori Organisasi Modern, Teori ini muncul pada tahun 1950 sebagai akibat ketidakpuasan dua teori sebelumnya yaitu Teori Organisasi Klasik dan Teori Organisasi Neoklasik. Teori Organisasi Modern sering disebut dengan teori "Analisa Sistem" atau "Teori Terbuka" yang memadukan antara Teori Organisasi Klasik dan Teori Organisasi Neoklasik. Teori Organisasi Modern melihat bahwa semua unsur organisasi sebagai satu kesatuan yang saling bergantung dan tidak bisa dipisahkan. Organisasi bukan sistem tertutup yang berkaitan dengan lingkungan yang stabil akan tetapi organisasi merupakan sistem terbuka yang berkaitan dengan lingkungan dan apabila ingin survive maka ia harus bisa beradaptasi dengan lingkungan.

Terkait dengan kajian Puskesmas sebagai organisasi publik, maka sesungguhnya Puskesmas mengenal prinsip-prinsip yang dikemukakan Teori Organisasi, baik Teori Organisasi klasik, Teori Organisasi Neoklasik, maupun Teori
Organisasi Modern. Dalam perspektif ini bahwa semua unsur organisasi seperti manusia, tujuan, kerjasama, dan prinsipprinsip termaktup dalam bagian ini. Untuk itu penting dilakukan kajian terhadap eksistensi Puskesmas sebagai garda terdepan dalam melakukan tugas dan fungsi primernya melayani kesehatan masyarakat di kampung-kampung si seantero Tanah Papua.

Data Badan Pusat Statistik Provinsi Papua tahun 2012 menyebutkan bahwa pusat kesehatan masyarakat (Puskesmas) di seluruh Provinsi Papua berjumlah 334 unit yang dilayani oleh 346 tenaga dokter umum, 50 orang dokter gigi dan 855 bidan. Dari jumlah ini, maka puskesmas terbanyak berada di Kabupaten Tolikara yaitu sebanyak 27 Puskesmas yang dilayani 25 orang dokter umum, dua orang dokter gigi dan 12 orang bidan, sedangkan urutan kedua Puskesmas terbanyak adalah Kabupaten Nabire dengan 20 unit Puskesmas yang dilayani 15 orang dokter umum, 4 orang dokter gigi dan 59 orang bidan.

Kabupaten Jayapura memiliki 17 Puskesmas yang dilayani 22 orang dokter umum, 4 orang dokter gigi dan 51 bidan, sedangkan Kota Jayapura tersebar 12 Puskesmas yang dilayani 14 orang dokter umum, 7 orang dokter gigi dan 134 bidan. Sementara Kabupaten Waropen memiliki 10 Puskesmas tanpa dokter umum dan dokter gigi. Di seluruh Puskesmas dilayani oleh 11 orang bidan. Artinya 1 Puskesmas hanya ada seorang bidan. Namun berbeda dengan Kabupaten Intan Jaya, yang secara struktur organisasi ada Puskesmasnya sebanyak 6 unit, namun sangat disayangkan bahwa tidak ada bidan, apalagi dokter umum dan dokter gigi.

Keadaan ini sesungguhnya menjadi keprihatinan bahwa Pemerintah (entah pemerintah pusat, provinsi, maupun 
kabupaten/kota) sudah seharusnya memberi "perhatian" ekstra dalam kaitannya dengan penguatan dan peningkatan kapasitas organisasi Puskesmas, sehingga sebagai basis pelayanan kesehatan masyarakat semakin lebih baik, dan warga dapat menikmati pelayanan kesehatan di Puskesmas secara lebih gampang, lebih mudah, lebih murah serta lebih hemat, dari aspek waktu dan biaya dari pada berobat ke dokter praktek yang cenderung lebih mahal.

\section{METODE PENELITIAN}

Penelitian ini menggunakan metode survey lapangan, dengan observasi dengan wawancara lepas kepada pihak terkait pelaksanaan pelayanan publik di Puskesmas- Puskesmas yang ada di Papua. Selain itu dalam penelitian ini data juga dikumpulkan melalui studi literatur. Artinya membaca buku-buku referensi yang berkaitan dengan topik kajian yakni, puskemas, organisasi publik, dan pelayanan publik, kemudian mengkombinasikannya dengan berbagai dokumen termasuk data-data. Data-data dan informasi yang telah dihimpun kemudian dianalisis dengan menggunakan pendekatan deskriptif kualitatif sehingga menghasilkan narasi yang menggambarkan tujuan dari kajian ini, dimana perspektif yang digunakan mengenai pelayanan di Puskesmas ditinjau dalam sudut pandang teori organisasi

\section{HASIL DAN PEMBAHASAN}

Tidak bisa disangkal bahwa Puskesmas memegang peranan penting dalam hal pelayanan kesehatan masyarakat. Umumnya letak sebuah Puskesmas berada pada kecamatan (distrik) sehingga diharapkan Puskesmas mampu melayani masyarakat dari beberapa kampung yang berada dalam sebuah wilayah distrik. Hanya saja, dalam Copyright (C 2018, Publik : (Jurnal Ilmu Administrasi), ISSN: 2301-573X (Print), ISSN: 2581-2084 (Online) beberapa kasus tidak jarang, Puskesmas tidak memiliki dokter, bidan dan fasilitas pelayanan yang dibutuhkan masyarakat. Kondisi ini dapat menjadi barometer bahwa tingkat dan derajat kesehatan masyarakat kita masih sangat jauh dari yang diharapkan. Secara kemampuan kita tentu tidak meragukan kapasitas dan kapabilitas para petugas kita yang telah dinyatakan lolos seleksi penerimaan PNS untuk menjadi tenaga kesehatan yang selanjutnya akan ditempatkan di desa-desa (kampung-kampung jika di Papua) namun tidak jarang ditemukan bahwa lebih banyak petugas kesehatan (dokter, bidan) meminta bertugas di kota daripada bertugas di daerah-daerah. Katakanlah pada data BPS seperti yang dikemukakan diatas bahwa pada beberapa daerah seperti: Kota Jayapura, Kabupaten Jayapura, Kabupaten Nabire dan Kabupaten Tolikara mengalami penumpukan bidan. Misalnya, pada sejumlah puskesmas di Kota Jayapura tercatat ada 134 orang bidan, sementara di kabupaten Waropen dan Kabupaten Intan Jaya tidak memiliki dokter dan juga perawat. Memang tidak mudah dalam mengatur soal distribusi petugas kesehatan karena terkandung banyak aspek misalnya tingkat kebutuhan, perbedaan motivasi, ketersediaan fasilitas pelayanan dan fasilitas penunjang tugas pekerjaan, serta beragamnya nilai insentif dan upah yang diterima.

Sampai sekarang kita tidak tahu kebutuhan pelayanan kesehatan masyarakat kita, yang terjadi adalah Pemerintah "merasa cukup" dengan menyediakan Puskesmas (bangunannya saja) tanpa dilengkapi dengan kebutuhan ideal yang benar-benar dibutuhkan masyarakat. Akibatnya, seperti yang diungkapkan tadi bahwa ada Puskesmas tapi tidak ada dokter dan petugas kesehatan lainnya. 
Puskesmas-puskesmas kita membutuhkan petugas kesehatan yang cukup besar, seperti dokter umum, dokter gigi, dan bidan. Jika memang untuk peningkatan kapasitas dan kualitasnya maka dibutuhkan beberapa orang spesialis dan tenaga apoteker serta sejumlah analis. Hal ini tentu saja berkaitan dengan sumber daya manusia (SDM) yang dibutuhkan oleh Puskesmas untuk menjawab kebutuhan masyarakat. Selain itu, apakah para petugasnya memang memiliki keahlian (keterampilan) dalam melakukan tugas-tugasnya. Sebab bukan tidak mungkin, secara organisasi seseorang tercatat sebagai pegawai pada satu unit organisasi pemerintah tapi apakah oknum atau individu tersebut mampu melakukan tugas dan fungsinya sebagai petugas kesehatan secara memadai? Tentu pertanyaan ini patut dikedepankan agar masyarakat kita lebih kritis dan jeli melihat berbagai fenomena pelayanan kesehatan khususnya di tingkat Puskesmas. Apalagi ada pemeo bahwa Puskesmas merupakan basis pelayanan kesehatan masyarakat di kampung-kampung.

Selain memiliki orang-orang dengan kualifikasi seperti yang telah dijelaskan tadi, maka setidaknya puskesmas harus ditopang dengan manajemen pelayanan puskesmas yang solid dan valid. Artinya bahwa Puskesmas harus memiliki standar pelayanan minimal (SPM) atau Standar Prosedur Pelayanan (Standard Operating Prosedure). Hal ini menjadi alat ukur keberhasilan pelayanan kesehatan kepada masyarakat. Misalnya saja, pada saat pasien datang di depan puskesmas, mulai mendaftar, proses pencatatan, pelayanan diagnosis, hingga mendapatkan obat dibutuhkan waktu berapa lama. Kemudian jenis obat-obat apa saja yang harus diberikan kepada pasien. Jenis dan standarnya serta ukurannya. Rakyat perlu tahu seperti apa kualitas layanan yang mereka terima, setidaknya mereka punya hak untuk mengetahui tindakan medis seperti apa yang mereka terima, dan konsekuensi logis apa yang terjadi dengan tindakan medis yang mereka terima. Semua ini setidaknya menjadi catatan penting untuk manajemen puskesmas. Kita harus bisa memikirkan pola dan cara-cara baru yang lebih efisien dan praktis serta murah dan mudah untuk dilakukan manajemen puskesmas agar tidak membebani rakyat kita pada saat mereka berobat di Puskesmas. Umumnya rakyat di kampung-kampung hanya mengandalkan Puskesmas sebagai tempat mereka berobat. Berbeda dengan rakyat di kota atau dipinggiran kota, yang memiliki alternatif lain untuk pengobatan, karena selain mengakses ke Puskesmas mereka bisa langsung ke Rumah Sakit (tanpa rujukan) atau ke klinik-klinik terdekat yang biasanya menjadi tempat bisnisnya dokterdokter pemerintah di luar jam dinasnya di Rumah Sakit Umum Daerah Provinsi atau Kabupaten/Kota.

Satu hal yang biasanya dilupakan Pemerintah melalui Satuan Kerja Perangkat Daerah (SKPD) atau dinas teknis yang mengurus bidang kesehatan adalah soal penyediaan fasilitas penunjang pelayanan kesehatan di Puskesmas. Penyediaan fasilitas ini biasanya terkait dengan kebutuhan-kebutuhan pelayanannya. Umumnya adalah fasilitas bagi tenaga medisnya berupa rumah tinggal yang berdekatan dengan Puskesmas, lalu fasilitas dan perabotan dalam rumah, serta fasilitas pendukung operasional Puskesmas diluar kebutuhan obat-obatan seperti ambulans dan lain sebagainya. Tentu saja untuk pemenuhan kebutuhan ini, jarang sekali dilakukan analisis kebutuhan berdasarkan tingkat kebutuhan rakyat di kampung-kampung. 
Inilah yang barangkali kurang tersentuh, sehingga tidak jarang petugas ogah-ogahan untuk bekerja melayani masyarakat dan lebih memilih "menghilang" ke tempat lain dari pada melakukan pekerjaannya di tempat tugas. Kadang fasilitas menjadi salah satu alasan petugas tidak berada di tempat. Tidak ada rumah, kalau pun ada rumah tidak ada alat penerang, atau tidak dilengkapi dengan air bersih. Kalaupun fasilitas rumah lengkap kadang hak-hak petugas (gaji dan jatah beras) termasuk insentif tidak diberikan tepat waktu, sehingga hal-hal ini menjadi alasan-alasan yang sebenarnya sangat klasik dan terdengar lucu saja, sebab terjadi berulangulang dan tidak pernah dibenahi. Oleh sebab itu, dalam kaitannya dengan penguatan kapasitas puskesmas sebagai basis pelayanan kesehatan masyarakat di kampung-kampung maka ketersediaan fasilitas dalam arti luas setidaknya menjadi pertimbangan yang harus dipikirkan dan harus ditemukan solusinya.

Selain fasilitas, pembiayaan operasional Puskesmas pun menjadi hal penting. Mengapa? Semua fasilitas yang dibutuhkan puskesmas tentu harus dibeli, makanya alokasi dana untuk operasional Puskesmas harus benar-benar dianalisa dan ditetapkan besarannya, sehingga dalam hal alokasi semua kebutuhan pembiayaan harus bisa terkover dalam dana APBD Kabupaten/kota dimana puskesmas itu berada.

Perilaku aparat kita disini adalah cenderung melakukan manipulasi anggaran untuk pemenuhan berbagai kebutuhan pembelanjaan. Makanya, dalam kaitannya dengan pemenuhan kebutuhan anggaran pembiayaan untuk operasional sebuah Puskesmas, dibutuhkan kepemimpinan (leadership), Kerjasama tim (tim work), partisipasi (Partisipation), komunikasi (communication), dan lainnya seperti yang dimaksudkan oleh teori organisasi yang Copyright @ 2018, Publik : (Jurnal Ilmu Administrasi), ISSN: 2301-573X (Print), ISSN: 2581-2084 (Online) diuraikan pada bagian atas tulisan ini. Sebab, bukan tidak mungkin, dengan kepemimpinan (leadership) yang solid akan menggerakkan struktur organisasi dalam menjalankan Manajemen Organisasi Puskesmas.

Perubahan Budaya Organisasi. Budaya Organisasi menjadi "sistem makna bersama" yang dianut para anggota organisasi Puskesmas yang membedakan organisasi tersebut dengan organisasi lainnya. (Robbins 2008:256). Budaya organisasi mengukur bagaimana anggota organisasi Puskesmas memandang organisasi tempatnya bekerja. Misalnya apakah ada upaya untuk mendorong terjadinya kerjasama tim, apakah menghargai inovasi, inisiatif, disiplin, dan sebagainya. secara eksplisit budaya organisasi yang kuat erat kaitannya dengan rendahnya perpindahan anggotanya. Budaya organisasi memiliki fungsi-fungsi :

Pertama, sebagai penentu batas-batas artinya budaya organisasi menciptakan perbedaan antara satu organisasi dengan organisasi lain. Dua, menjadi identitas anggota organisasi puskesmas. Tiga, memfasilitasi sesuatu yang lebih besar daripada kepentingan individu. Empat, sebagai alat perekat sosial. Lima, sebagai alat kontrol yang menuntun pada pembentukan perilaku.

Berikut adalah hakekat budaya organisasi, yaitu : satu, Inovasi-inovasi dalam hal model dan konsep pelayanan serta berani mengambil resiko; dua, Perhatian pada hal-hal detail. Tiga, Orientasi pada hasil. Artinya hasil kerja harus menjadi prioritas utama. Empat, Orientasi pada orang. Artinya bahwa manusia dalam organisasi pada dasarnya merupakan faktor utama dalam organisasi. oleh sebab itu, organisasi yang berorientasi manusia pada hakikatnya dapat mencapai tujuannya. Manusia menjadi penentu keberhasilan organisasi. meski demikian, 
dapatlah disebutkan bahwa orientasi ini sering dilupakan dalam prakteknya. Pengabaian terhadap karier seseorang atau ketidakpedulian terhadap bawahan juga menjadi kontradiksi dengan bagaimana membangun budaya organisasi yang etis atau tanggap terhadap pelanggan. Lima, Orientasi tim. Hasil kerja puskesmas merupakan kinerja tim, dimana di puskesmas semua pekerjaan dikerjakan secara bersama-sama (tim). Enam, Keagresifan. Agresif dimaksudkan bagaimana anggota organisasi Puskesmas berlomba-lomba atau berkompetisi secara sehat melakukan yang terbaik. (hal-hal yang tepat). Ketepatan melakukan sesuatu yang baik pada dasarnya merupakan ciri membangun budaya organisasi dan merupakan salah satu kultur kuat dari organisasi. Tujuh, stabilitas. Stabilitas dalam membangun budaya atau kultur organisasi yang etis dan tanggap pelanggan. Artinya bahwa stabilitas bukan mempertahankan "status quo" atau sesuatu yang negatif. Sebaliknya "status quo" dalam konteks membangun kultur organisasi yang etis dan tanggap pelanggan. Hal ini sebenarnya merupakan niat suci untuk menjaga citra Puskesmas sebagai organisasi publik yang bertugas melakukan pelayanan kesehatan kepada masyarakat. Sebagai bagian terakhir dari tulisan ini, saya mau menyampaikan bahwa untuk mendekatkan pelayanan kesehatan yang layak dan bermutu prima kepada masyarakat dapat dimulai dengan optimalisasi tugas dan fungsi Puskesmas sebagai organisasi publik

\section{PENUTUP}

\section{Kesimpulan}

Memang tidak mudah untuk menyelesaikan masalah-masalah yang berkaitan dengan penataan organisasi Puskesmas sebagai basis Pelayanan
Kesehatan masyarakat, serta bagaimana Puskesmas menjalankan tugas pokok dan fungsinya, serta mengatasi kendalakendala manajemen puskesmas, serta masalah sumber daya manusia petugas yang berdinas di Puskesmas, hal yang harus dilakukan adalah bagaimana penataan Struktur Organisasi Puskesmas. Dalam perspektif Teori Organisasi Puskesmas dipandang sebagai organisasi publik memiliki hubungan dan keterkaitan dengan struktur organisasi, dimana pada struktur organisasi biasanya melekat unsurunsur :

- Tanggung jawab, tanggung jawab setiap orang yang bekerja di puskesmas akan terlihat melalui struktur organisasinya.

- Kewenangan (otoritas), kewenangan yang dimilikipun akan menjadi legitimasi ketika sebuah keputusan diambil berdasarkan tugas

- Tugas dan fungsi (tusi). Tusi akan terlihat jelas dalam struktur organisasi dimana bidang-bidang kerja yang menjadi tujuan pelayanan organisasi.

- Hirarki, dalam struktur organisasi akan terlihat jelas, bahwa siapa yang menjadi pimpinan dan siapa yang menjadi bawahan. Pimpinan akan terlihat kewenangannya dan hasil pekerjaan dilaporkan ke mana, Singkatnya siapa melaporkan kepada siapa.

- Hubungan kerja. hubungan kerja akan terlihat melalui garis-garis pada struktur organisasi, dimana hubungan kordinasi dan hubungan langsung atas garis komando.

- Serta sistem informasi organisasi.

Saran

Optimalisasi peran, tugas dan fungsi Puskesmas tentu harus diikuti dengan komitmen, kepemimpinan, perubahan cara 
pandang, pengaturan regulasi, dan kemauan yang kuat untuk memperbaiki kinerja Puskesmas. Puskesmas merupakan citra diri atau potret/wajah pemerintah kita, sebab apapun alasannya, sektor kesehatan merupakan urusan wajib pemerintah yang mau tidak mau suka tidak suka harus dilakukan sebagai bagian dari tugas dan fungsi negara. Semoga Puskesmaspuskesmas kita semakin memacu dirinya untuk lebih meningkatkan pelayanannya kepada masyarakat kita yang hampir 80 persen berdiam di kampung-kampung dimana puskesmas itu berada.

\section{DAFTAR PUSTAKA}

Greenberg Jerald and Roberth A Baron. (2003). Behavior in Organization. New Jersey: Pearson Education, Inc.

Kusdi. (2009) Teori Organisasi dan Administrasi. Jakarta : Salemba Humanika

Miftha Thoha. (2012). Perilaku Organisasi, Konsep Dasar dan Aplikasinya Jakarta : Radja Grafindo Persada

Provinsi Papua dalam Angka. (2012). Badan Pusat Statistik: Provinsi Papua.

Robbins Stephen. (1998) Teori Organisasi : Struktur Desain dan Aplikasi, Edisi III Jakarta : Arcan

(2008). (Organization Behavi 12. Jakarta : Person Education dan Salemba Empat

Maniagasi YG. (2014). Perilaku Birokrasi Pelayanan Publik, Studi Kasus Pelayanan Kesehatan pada RSUD Yowari Kabupaten Jayapura (Tesis Magister) Universitas Hasanuddin, Makassar. 